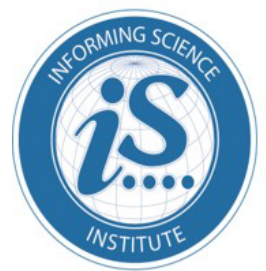

Interdisciplinary Journal of Information, Knowledge, and Management

Volume 12, 2017

\title{
A SySTEMATIC Literature REVIEW OF AGILE AND MATURITY MODEL RESEARCH
}

\author{
Vaughan Henriques* \\ University of Cape Town, \\ vaughanhenriques@gmail.com \\ Cape Town, South Africa \\ Maureen Tanner \\ University of Cape Town, \\ mc.tanner@uct.ac.za \\ *Corresponding Author

\begin{abstract}
Background/

Aim/Purpose

A commonly implemented software process improvement framework is the capability maturity model integrated (CMMI). Existing literature indicates higher levels of CMMI maturity could result in a loss of agility due to its organizational focus. To maintain agility, research has focussed attention on agile maturity models. The objective of this paper is to find the common research themes and conclusions in agile maturity model research.
\end{abstract}

Methodology This research adopts a systematic approach to agile maturity model research, using Google Scholar, Science Direct, and IEEE Xplore as sources. In total 531 articles were initially found matching the search criteria, which was filtered to 39 articles by applying specific exclusion criteria.

Contribution The article highlights the trends in agile maturity model research, specifically bringing to light the lack of research providing validation of such models.

Findings Two major themes emerge, being the coexistence of agile and CMMI and the development of agile principle based maturity models. The research trend indicates an increase in agile maturity model articles, particularly in the latter half of the last decade, with concentrations of research coinciding with version updates of CMMI. While there is general consensus around higher CMMI maturity levels being incompatible with true agility, there is evidence of the two coexisting when agile is introduced into already highly matured environments.

Future Research Future research direction for this topic should include how to attain higher levels of CMMI maturity using only agile methods, how governance is addressed in agile environments, and whether existing agile maturity models relate to improved project success.

Keywords Agile, Scrum, XP, Maturity Model, Agile Maturity Model, Agile Process Improvement

Accepted by Editor Harry Tomas Fulgencio | Received: September 20, 2016 | Revised: November 26, 2016; January 14, February 14, 2017 | Accepted: February 20, 2017.

Cite as: Henriques, V., \& Tanner, M. (2017). A systematic literature review of agile and maturity model research. Interdisciplinary Journal of Information, Knowledge, and Management, 12, 53-73. Retrieved from http://www.informingscience.org/Publications/3666

(CC BY-NC 4.0) This article is licensed it to you under a Creative Commons Attribution-NonCommercial 4.0 International License. When you copy and redistribute this paper in full or in part, you need to provide proper attribution to it to ensure that others can later locate this work (and to ensure that others do not accuse you of plagiarism). You may (and we encourage you to) adapt, remix, transform, and build upon the material for any non-commercial purposes. This license does not permit you to use this material for commercial purposes. 


\section{INTRODUCTION}

The adoption of agile methodologies is continuously on the rise, even in large corporate environments (VersionOne, 2016). This increased adoption rate can be attributed to the success of these methodologies and a number of research studies have documented this phenomenon worldwide (Dingsøyr, Nerur, Balijepally, \& Brede Moe, 2012). Currently, research articles focus on issues related to critical success factors for agile implementations (Chow \& Cao, 2008), project success relative to traditional plan driven methods (Ambler, 2014), maturity models, and adoption frameworks (Fontana, Meyer, Reinehr, \& Malucelli, 2015), and organisational (Iivari \& Iivari, 2011) and people (McHugh, Conboy, \& Lang, 2012) considerations.

Principle twelve of the agile manifesto, "At regular intervals, the team reflects on bow to become more effective, then tunes and adjusts its behavior accordingly" (Fowler \& Highsmith, 2001, p. 34), encourages the continual improvement of the software delivery process. The most commonly used approach is the use of software process improvement (SPI) or maturity models, with the Capability Maturity Model Integrated (CMMI) being the most widely used (Leppänen, 2013). Although high levels of CMMI maturity has been shown to improve project success (Humble \& Russel, 2009) in waterfall environments (Galin \& Avrahami, 2006), these higher maturity levels have been found to be incompatible with agile environments without sacrificing the initial agility being sought (Fritzsche \& Keil, 2007). This incompatibility has been ascribed to the different focus areas between agile methods and CMMI, with agile focussing on project delivery and CMMI focussing more on the organisational level (Fritzsche \& Keil, 2007; Łukasiewicz \& Miler, 2012). Given the scope changes allowed, the highly collaborative approach and independent and self-organising team approach of agile methods, an agile principle based maturity model is better suited for use in these environments (Gren, Torkar, \& Feldt, 2015). In an effort to maintain agility, research has explored the concept of an agile principle-based maturity model, amongst others for example Ambler (2010), Buglione (2011), Fontana, Fontana, da Rosa Garbuio, Reinehr, and Malucelli (2014), Humble and Russel (2009), Jakobsen and Johnson (2008), and Patel and Ramachandran (2009).

The objective of this research is to provide a summary of the research which has been conducted in the field of agile methods, specifically in the context of agile maturity models. The specific research questions being addressed are "What are the trends in research concerned with agile methods in the context of agile maturity models?", "What are the research themes in this topic?" and "What conclusions can be extracted from current research?" A systematic literature review approach, using the guidelines as prescribed by Kitchenham and Charters (2007) was employed to achieve the stated objective. Three online electronic databases were searched using search terms relating specifically to agile methods and SPI (refer to section "Search Synonyms and Combinations" for details). An initial list of 531 articles were obtained, which were filtered down to 39 articles relevant to this research which were further analysed for this paper.

The remainder of this paper is structure as follows. The next section covers the research method and planning of the research used in producing this systematic review. The section on search results provides the details on conducting the search, followed by the analysis and discussion. The final section draws useful conclusions in answering the research questions previously presented. Further to answering the research questions this research contribution will also highlight gaps in the current literature, proposing possible future research direction in agile maturity.

\section{RELATED REVIEWS}

This sub-section summarises similar systematic literature review focussing on the topic of agile maturity models. An online search shows only a single article specifically focussed on the specific topic mentioned. Schweigert, Vohwinkel, Korsaa, and Nevalai (2013) provide a systematic review of agile maturity model research from the perspective of rating existing agile maturity models relative to the 
associated ISO/IEC 15504 Part 2 standard for maturity models. The paper further provides a map of existing maturity models to the stated standard.

Opposed to focussing on agile maturity models, other articles focus on summary research regarding using CMMI in combination with agile methods, e.g., Silva et al. (2015), focussing specifically on the benefits, limitations, and strengths thereof. Similarly, Dybå and Dingsøyr (2008) conducted a systematic review to ascertain the benefits, limitations, strengths, and implications of adopting agile implementation methods.

Kuhrmann, Diebold, and Münch (2016) and von Wangenheim, Hauck, Salviano, and von Wangenheim (2010) provide a systematic mapping study and systematic reviews respectively focussing specifically on the use of agile methods with software process improvement (SPI) models, concluding the majority of the research is focussed on the co-existence of agile and CMMI.

\section{RESEARCH METHOD}

The research method employed follows guidelines for systematic literature reviews as stipulated in Kitchenham and Charters (2007). The review process was conducted systematically in three stages: planning, conducting, and reporting of the review.

\section{DATA SOURCES, INCLUSION AND EXCLUSION CRITERIA}

The search was limited to English papers, available in online journals, including published journals with online content and conference proceedings. The electronic databases used for the search were Google Scholar (scholar.google.com), IEEEXplore (ieeexplore.ieee.org) and ScienceDirect (sciencedirect.com).

Kitchenham and Charters (2007) caution against limiting results too soon, specifically for information technology related systematic literature reviews as well as avoiding publication bias. To address the former concern, the search strategy was not limited to a specific industry, with the latter concern being addressed by the inclusion of conference and workshop proceedings as well as unpublished thesis and/or dissertations in the search strategy. The only limitation placed on the date of the publication was that it had to have been published after 2000 since this is when the agile manifesto was conceptualised (Fowler \& Highsmith, 2001). The search was limited to the search words specified in Table 1 explicitly occurring in the title, abstract, or keyword to ensure results were for articles focussing on the research subject. The exclusion criteria applied were the following: the paper needed to be specific to information technology/software development, based on primary research and full text available for download. The results of applying the inclusion and exclusion criteria are presented in the Results section.

\section{SEARCH SYNONYMS AND COMBINATIONS}

The following section details the rationale applied in formulating the search terms used for conducting the initial article search.

\section{Agile methods}

The agile manifesto (Fowler \& Highsmith, 2001) is considered the birth of modern agile methodologies, yet research shows it was the culmination of principles and values of the primary iterative development methodologies in use at the time. Iterative and incremental design and development (IIDD) methods were used in software development as early as the mid nineteen fifties (Glazer, Dalton, Anderson, \& Konrad, 2008). Implementing the principles of Deming's Plan-Do-Check-Act (PDCA) cycle (Glazer et al., 2008) which was created in the nineteen thirties (Johnson, 2002), IIDD sought constant feedback and collaboration in implementing a continuous process improvement approach while developing software or a product to ensure customer satisfaction (Johnson, 2002). 
More modern day variants of agile, such as eXtreme Programming (XP), Scrum, Feature Driven Development (FDD), Crystal and the Rational Unified Process (RUP) came into being in the nineteen nineties (Glazer et al., 2008) after IIDD was popularised in various American government organisations in the nineteen seventies and subsequently adopted in corporate environments in the nineteen eighties. Ultimately, in February 2001, the thought leaders behind these methodologies congregated in Snowbird Utah to compile the agile manifesto (Glazer et al., 2008).

Having its origins in the PDCA cycle, the agile manifesto is not prescriptive in the specific methodology employed; instead it provides the guiding values and principles. Recent surveys of agile implementations worldwide show thirteen methodologies being used, with Scrum being most predominant (VersionOne, 2016). As the current research is not limited to any specific agile methodology, the search synonyms used must cover the popular agile methods as well as the iterative concept underpinning agile methodologies. The search synonyms used for agile are as shown in Table 1.

\section{Maturity models}

A maturity model describes how a process can evolve (mature) over time. Each phase of evolution, referred to as a maturity level, indicates a progression on the improvement path, increasing the desired outcome of the process (Fontana et al., 2015). The most commonly followed maturity model is the Capability Maturity Model Integrated (CMMI) (Leppänen, 2013), with the Software Process Improvement and Capability Determination (SPICE) (Schweigert, Vohwinkel, Korsaa, Nevalainen, \& Biro, 2014) being another used for maturing software practices. The synonyms used in searching for maturity models thus need to encompass CMMI, SPICE, and continuous improvement as listed in Table 1.

Table 1. List of synonyms for Agile and Maturity Models

\begin{tabular}{|c|c|}
\hline Synonyms for "Agile" & Synonyms for "Maturity Model" \\
\hline $\begin{array}{ll}\text { i) } & \text { Agile } \\
\text { ii) } & \text { Scrum } \\
\text { iii) } & \text { XP } \\
\text { iv) } & \text { Extreme Programming } \\
\text { v) } & \text { Pair Programming } \\
\text { vi) } & \text { Iterative Development }\end{array}$ & $\begin{array}{ll}\text { i) } & \text { Maturity Model } \\
\text { ii) } & \text { Capability Maturity } \\
\text { iii) } & \text { Process Improvement } \\
\text { iv) } & \text { Software Maturity } \\
\text { v) } & \text { CMM } \\
\text { vi) } & \text { CMMI }\end{array}$ \\
\hline
\end{tabular}

To formulate the search string used to find an initial list of papers, each of the synonyms listed for "Agile" was combined using a logical "AND" operation in a search string with a synonym for "Maturity Model", e.g., Agile AND Maturity Model giving 36 possible search strings, as shown in Appendix A - Search Strings.

\section{RESULTS}

The search and refinement process followed four stages as depicted in Figure 1 further described in this section. Stage 1, "Conducting Initial Research" consisted of applying the inclusion criteria previously mentioned, with each of the search strings entered into the databases previously specified, resulting in a total of 531 articles. The search results from each database search were extracted into EndNote (X4) reference manager. 


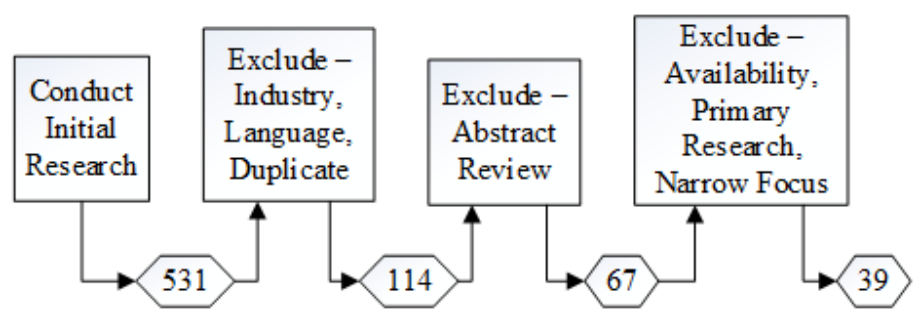

Figure 1. Applying inclusion and exclusion criteria and resulting number of articles

The following three stages focussed on applying the exclusion criteria previously mentioned, the results of which are discussed. By not limiting the initial search to a specific industry a large proportion of the initial results were obtained from either the chemical and/or the industrial engineering discipline due to the term "Process Improvement". Having searched using the same search expressions across a number of databases further inflated the initial results with a number of duplicate articles. Limiting the articles to English publication, with the removal of duplicate titles and the remaining titles being checked for relevance to agile software development and software maturity models, including the acceptable synonyms listed previously resulted in 114 articles, refer to Figure 1.

Prior to downloading the articles the abstract was reviewed to ascertain whether the article focussed on the research topic and would be able to contribute to answering the research questions posed. Applying this exclusion criterion resulted in 67 articles.

The final set of exclusion criteria applied was the availability of the article for download, the utilization of primary research, whether it provided a clear objective for the study, and whether it had a sufficiently broad focus. For example, some articles were limited to only the requirements management aspect of software engineering. As the focus of this research is a holistic perspective on agile maturity models, such narrowly focussed articles were excluded. This resulted in a final working set of 39 articles to be analysed.

\section{SOURCE OF ARTICLES}

Figure 2 shows the distribution of the original 531 articles by the search source. The majority of the articles (53\%, 279 articles) were found in the Google Scholar search with remainder being split between IEEE Xplorer (30\%, 160 articles) and Science Direct (17\%, 92 articles).

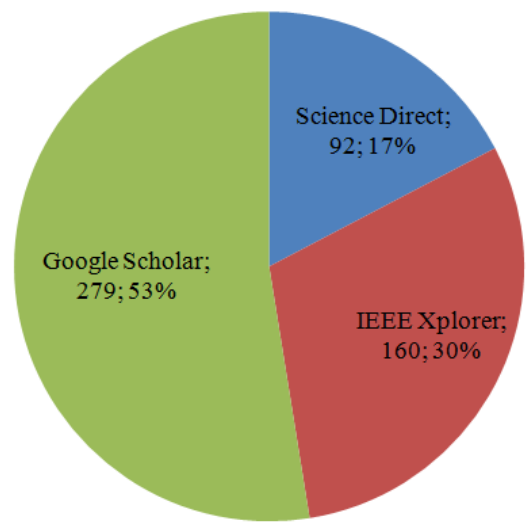

Figure 2. Distribution of initial search results by source

\section{PUBLICATION TYPE}

Figure 3 shows the distribution of the articles reviewed by type of publication. As evidenced the articles were obtained from a range of publication type with the majority (44\%, 17 articles) obtained from conference proceedings, 41\% (16 articles) from published journals, 10\% (4 articles) from un- 
published theses or technical reports with the remainder (5\%, 2 articles) from workshop proceedings. The inclusion of articles from these different sources in the analysis addresses potential publication bias (Kitchenham \& Charters, 2007).

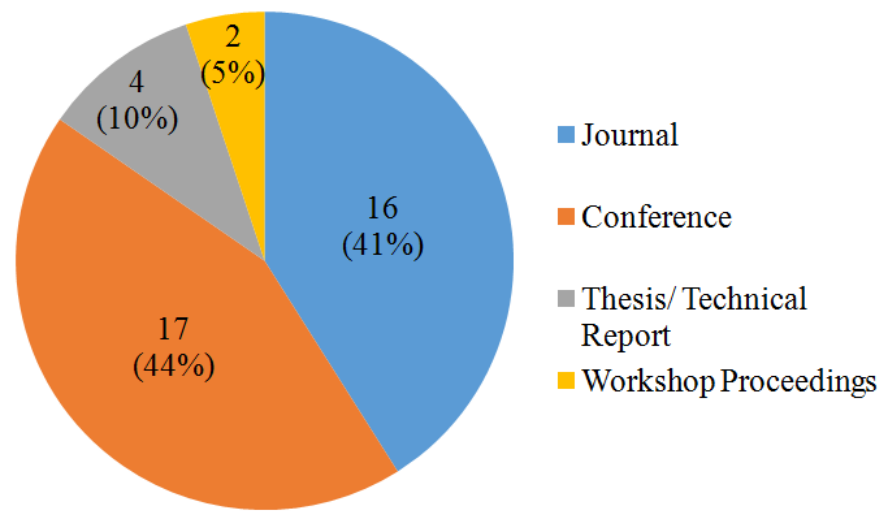

Figure 3. Distribution of articles by publication type

\section{YEAR OF ARTICLE}

Table 2 shows the distribution of articles retrieved by the year in which it was published or authored, in the case of unpublished works. The number of articles remains fairly constant but for two noticeable peaks in 2008 and 2011-2012, further discussed in the following section.

Table 2. Distribution of articles by year

\begin{tabular}{l|c|c|c|c|c|c|c|c|c|c|c|c|c|c|c} 
Yeat & 2001 & 2002 & 2003 & 2004 & 2005 & 2006 & 2007 & 2008 & 2009 & 2010 & 2011 & 2012 & 2013 & 2014 & 2015 \\
\hline Articles & 2 & 0 & 1 & 0 & 2 & 1 & 3 & 8 & 3 & 2 & 4 & 6 & 3 & 2 & 2 \\
\hline Percentage & $5 \%$ & $0 \%$ & $3 \%$ & $0 \%$ & $5 \%$ & $3 \%$ & $8 \%$ & $21 \%$ & $8 \%$ & $5 \%$ & $10 \%$ & $15 \%$ & $8 \%$ & $5 \%$ & $5 \%$
\end{tabular}

\section{POTENTIAL LIMITATIONS OF THIS REVIEW}

Though this research followed the guidelines as stipulated by Kitchenham and Charters (2007) for conducting a systematic review, it is not without limitations. Systematic reviews are typically conducted by a number of researchers, whereas this research was conducted by an individual. A further limitation is the number of digital sources utilized, thus limiting the number of articles in the initial search. However the number of duplicate articles found across the different databases indicates sufficient coverage by the selected databases. Therefore, the results of this systematic review are adequate in addressing the research questions.

\section{Discussion AND ANALYSIS}

The 39 articles were reviewed and catalogued by author and year of publication and categorised according to the theme being addressed. The thematic cataloguing followed a two phase approach. In the first phase the full text of each article was reviewed, specifically the stated intention and research questions were examined to determine the theme being addressed. The initial phase deliberately allowed for a number of categories so as not to generalize the categorization. Thereafter the articles were reviewed to ascertain whether the broad categories from phase one can be grouped into major theme categories. This catalogue was then used for further descriptive analysis as represented in the following subsections. 


\section{RESEARCH ACTIVITY BY YEAR}

Figure 4 depicts the yearly percentage distribution of research articles found between 2001 and 2015 (inclusive). Immediately evident is the prominent increase in research efforts in 2008, contributing 21\% (8 articles) and a cluster from 2011 to 2012 contributing 25\% (10) of the articles.

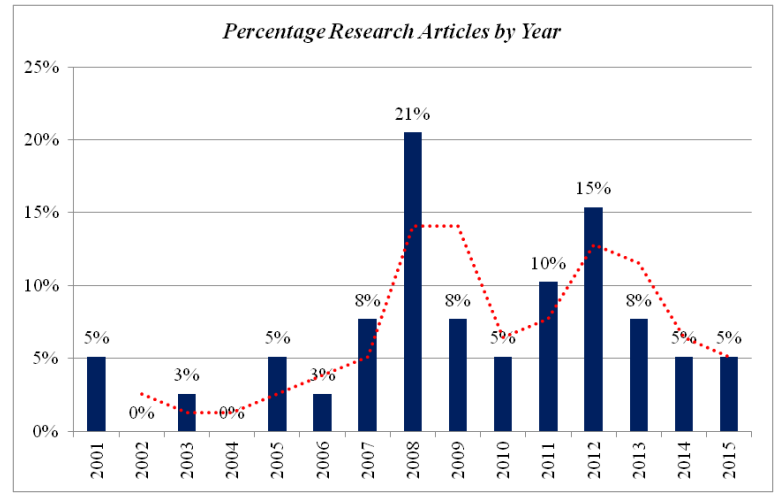

Figure 4. Percentage distribution of research articles by year

Notably these peaks of research lag the release of the updated versions of CMMI version 1.2 in 2006 and version 1.3 in 2010 by two years. The years preceding and following these research peaks also show higher percentages than other years. It can thus be deduced the research interest increased in the area of agile maturity, potentially triggered by the changes in the CMMI versions.

A possible explanation for these peaks of interest is apparent when reviewing the proposed improvements of these version updates. The first version of the Capability Maturity Model (CMM) published by the Software Engineering Institute (SEI) of the Carnegie Mellon University in 1991 (Team, 2010). Multiple implementations of CMM by practitioners were consolidated by SEI into a single version, the CMM Integrated (CMMI) in 2000, with the first updated version 1.2 being released in 2006 and version 1.3 in 2010. The 2006 CMMI version 1.2 update saw the introduction of maturity models focussing on three different disciplines, termed constellations in CMMI parlance. The first of these constellations was specifically focussed on software development and officially named CMMI-Dev (Heffner, 2006; Kitson, Vickroy, Walz, \& Wynn, 2009). Amongst other changes, the 2010 CMMI version 1.3 release included changes addressing implementation in agile environments (SEI, 2010) which potentially accounts for the increased interest in related research in 2011 and 2012. Versions 1.0 and 1.1 of the CMMI were released in 2000 and 2002 respectively, yet there is a notable absence of a corresponding increase in research activity in the following years. Since the agile manifesto was published in 2001, it can be argued that agile methods were immature and not in use in mainstream development to warrant significant research effort. Besides the two peaks the research interest in remains between $3 \%$ and $5 \%$.

\section{RESEARCH THEMES}

This section presents the results of the analysis conducted on the 39 articles. The section is structured to initially present and analyse the major research theme groupings and trends. Thereafter the sub themes in each of the groupings are analysed for trends and common conclusions.

\section{Major research themes}

Conducting an initial analysis and review of each article resulted in two major emerging themes, being Agile/CMMI and Agile Maturity. The former (Agile/CMMI) is primarily concerned with the coexistence of agile methods in an environment in which CMMI is present while the latter (Agile Maturity) is primarily concerned with improvement of agile implementation without concern for other process improvement frameworks, focussing on defining agile based improvement paths leading to improved agility (Leppänen, 2013). These themes are consistent with previous findings by Fontana et 
al. (2015) which found two focus areas of agile maturity research being "adapting agile practices and principles to fit current software maturity models" (Fontana et al., 2015, p. 89) and creating agile maturity paths aligned to the agile manifesto (Fontana et al., 2015).

Major Theme 1 - Agile/CMMI. Articles, numbers A3, A4, A7-A12, A14, A15, A18, A19, A22, A24, A26-A33 and A39 in Table B1 (Appendix B - Summary of cataloguing and categorisation of research articles by primary research themes) focussing on the Agile/CMMI theme, pose variants of the question "How to make Agile work in a CMMI environment?". The analysis shows 59\% (23) of the articles (see Figure 5) focussing on theme 1, with CMMI stated explicitly in either the title or abstract of the research or mentioned as the objective of the research.

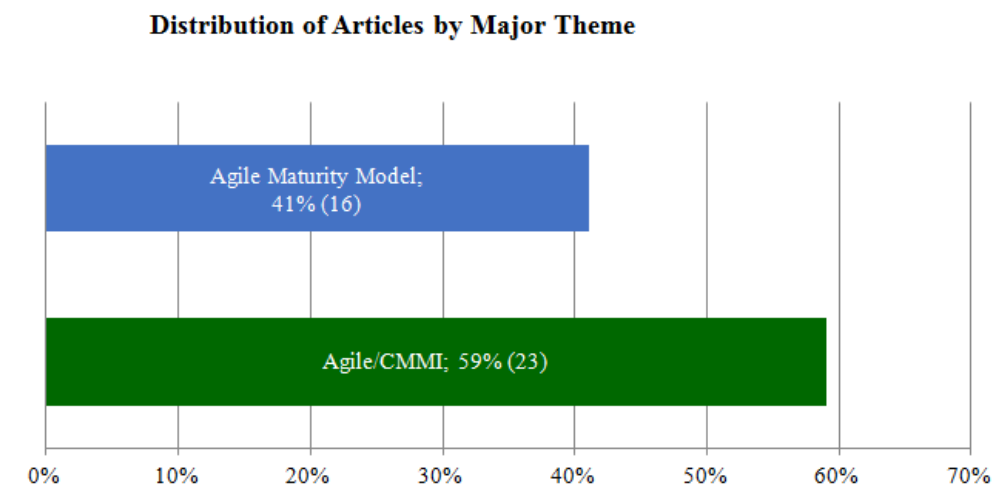

Figure 5: Distribution of articles by major theme

A plot of the yearly distribution of articles within theme 1, see Figure 6, corresponds to the yearly distribution previously noted, with peaks of research occurring in 2008 (18\% $=7$ articles) and 2012 $(15 \%=6$ articles $)$. CMMI remains the predominant software development process maturity framework in use (Leppänen, 2013), with organisations having invested significantly in harnessing its benefits (Galin \& Avrahami, 2006).

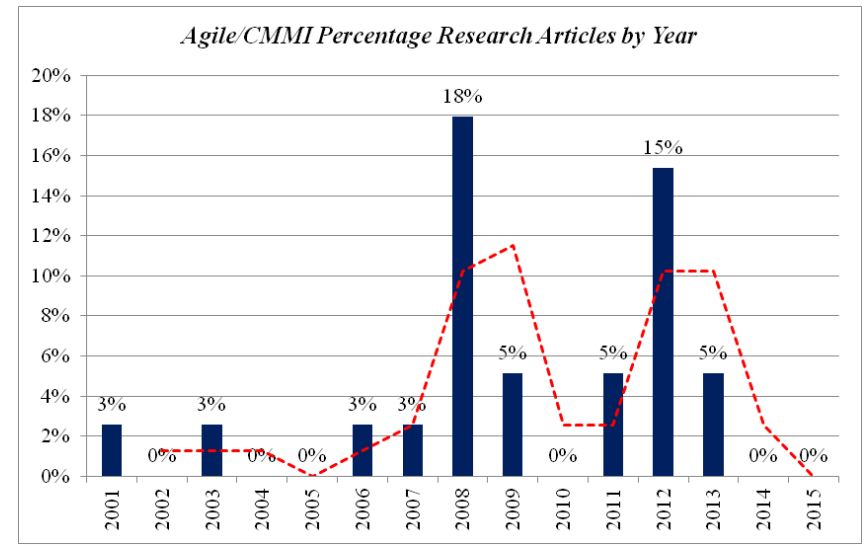

Figure 6: Percentage distribution of Agile/CMMI research articles by year

Studies have found successful implementations of agile methods are most likely in mature CMMI environments (Sutherland, Jakobsen, \& Johnson, 2008). Empirical studies have shown organisations require between seven (Shrum \& Phillips, 2004) and ten years (Galin \& Avrahami, 2006) to reach higher levels of maturity. Given the significant investment in advancing in CMMI maturity and the continued increase in agile adoption (VersionOne, 2016), the considerable increase in research attention in the coexistence of agile and CMMI is perhaps unsurprising, coinciding with the updated versions of CMMI. 
Major Theme 2 - Agile Maturity. Articles, numbers A1, A2, A5, A6, A13, A16, A17, A20, A21, A23, A25 and A34-A38 in Table B1 (Appendix B - Summary of cataloguing and categorisation of research articles by primary research themes) focussing on the Agile Maturity pose variants of the question "What is the best way to mature or adopt agile methods?". The analysis shows $41 \%$ (16) of the articles (see Figure 5) focussing on this theme.

Reviewing these articles in groupings of three year periods shows an increasing trend in the topic of agile maturity. Figure 7 depicts this increasing trend with 31\% (5) of the articles having been published in the last three years and over half, 56\% (9 articles) published since 2010. The increase in the occurrence of this theme coincides with the yearly increase in agile usage being reported over the same period in large corporate environments (VersionOne, 2016). Over the same period from 2010 to 2015 , there is a notable corresponding decreasing trend in the Agile/CMMI articles.

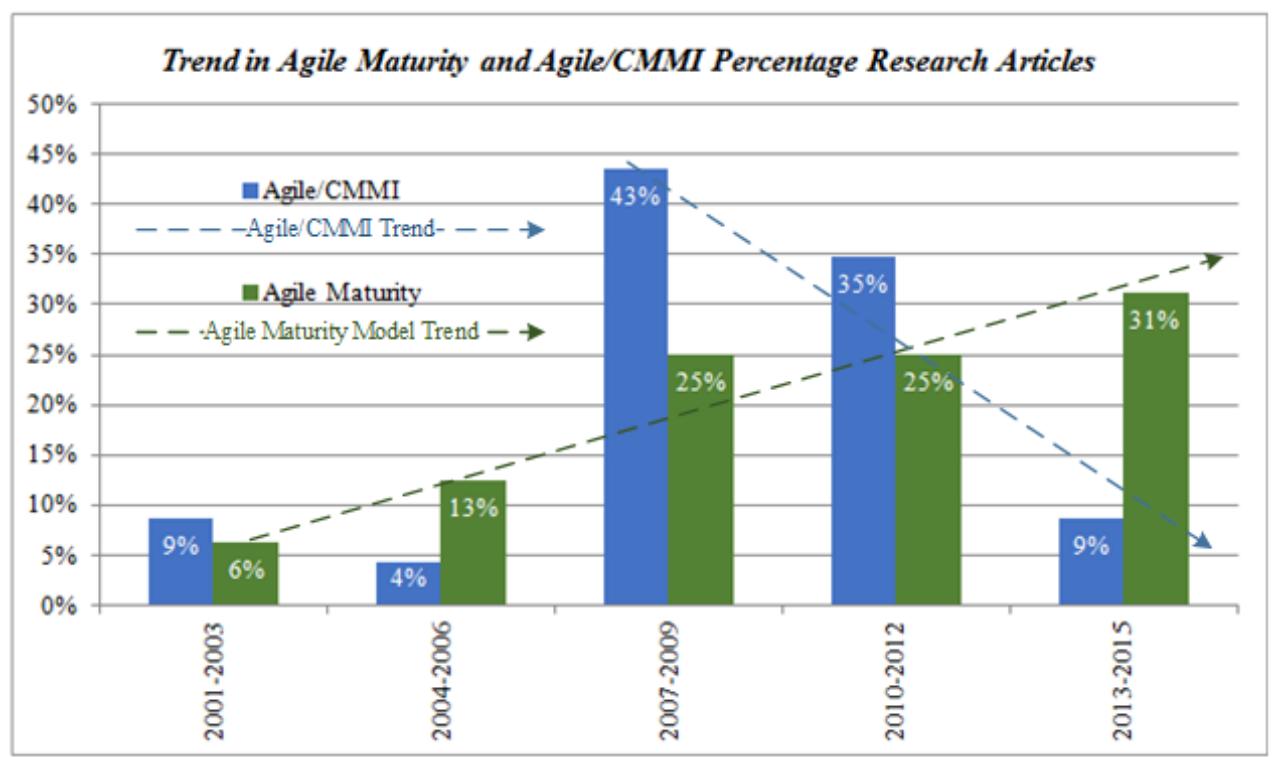

Figure 7: Trend in Agile Maturity and Agile/CMMI Research Articles

\section{Sub themes}

The introduction and objective sections of the articles of each major theme were further analysed to determine common groupings based on the research theme of the article. This review process resulted in six sub themes across the 39 articles. These sub themes are shown in Table 3 , with more detailed descriptions of each sub theme. A complete mapping of each of the articles to the corresponding sub theme is presented in Table B1 of Appendix B - Summary of cataloguing and categorisation of research articles by primary research themes. The remainder of this subsection discusses the detail of each of these sub themes and the conclusions emerging.

Agile/CMMI Sub Themes. Analysis shows the Agile/CMMI major theme can further be divided in two sub themes: "How can agile methods and CMMI be used simultaneously?" i.e., merging of Agile and CMMI, and "What is the mapping between a given CMMI level and/or process area and agile practices?" i.e., Agile/CMMI Mapping. Of the articles initially categorised into the Agile/CMMI major theme, $61 \%$ (14 articles) focus on the merging of agile and CMMI (refer to Figure 8). Examples of the coexistence of agile and CMMI are found in Fritzsche and Keil (2007), Glazer et al. (2008), and Lukasiewicz and Miler (2012). The latter sub theme is addressed in research concentrating on specific process areas, for example, Marçal et al. (2008) focussing only on project management process areas, Potter and Sakry (2009) researching a number of process areas across maturity levels, and Sutherland et al. (2008) providing a case study of introducing Scrum into a CMMI level five organisation. 
Table 3. Research themes emerging from review of articles

\begin{tabular}{|c|c|c|}
\hline $\begin{array}{l}\text { Major } \\
\text { Research } \\
\text { Theme }\end{array}$ & $\begin{array}{l}\text { Primary } \\
\text { Research } \\
\text { Theme }\end{array}$ & Description of research theme \\
\hline \multirow[t]{2}{*}{$\begin{array}{l}\text { Agile/ } \\
\text { CMMI }\end{array}$} & $\begin{array}{l}\text { Agile/ } \\
\text { CMMI Map- } \\
\text { ping }\end{array}$ & $\begin{array}{l}\text { Theme of these research articles are how agile practices satisfy the different process areas } \\
\text { of CMMI maturity levels }\end{array}$ \\
\hline & $\begin{array}{l}\text { Merging Ag- } \\
\text { ile and } \\
\text { CMMI }\end{array}$ & $\begin{array}{l}\text { The objectives of these studies are to either find ways in which an agile methodology can } \\
\text { be introduced into a CMMI environment or supplement CMMI processes }\end{array}$ \\
\hline \multirow[t]{4}{*}{$\begin{array}{l}\text { Agile } \\
\text { Maturity }\end{array}$} & $\begin{array}{l}\text { Agile Adop- } \\
\text { tion Frame- } \\
\text { work }\end{array}$ & $\begin{array}{l}\text { The objectives of these research articles are to find ways of introducing agile implemen- } \\
\text { tation methods into an environment, with no mention of CMMI or any other software } \\
\text { process improvement or maturity methodology in place }\end{array}$ \\
\hline & $\begin{array}{l}\text { Agile Maturi- } \\
\text { ty Model } \\
\text { Comparative } \\
\text { Study }\end{array}$ & $\begin{array}{l}\text { These articles analyse existing agile maturity models and perform a comparative study } \\
\text { across proposed models }\end{array}$ \\
\hline & $\begin{array}{l}\text { Agile Maturi- } \\
\text { ty Model } \\
\text { Proposed }\end{array}$ & $\begin{array}{l}\text { In this theme, authors use empirical methods to develop and propose a maturity model } \\
\text { for agile environments, discarding CMMI or similar process improvement frameworks }\end{array}$ \\
\hline & $\begin{array}{l}\text { Agile Maturi- } \\
\text { ty Model } \\
\text { Assessment }\end{array}$ & $\begin{array}{l}\text { Articles with this theme provide a means to either assess the level of agile maturity pre- } \\
\text { sent in an environment or the agility in an agile implementation }\end{array}$ \\
\hline
\end{tabular}

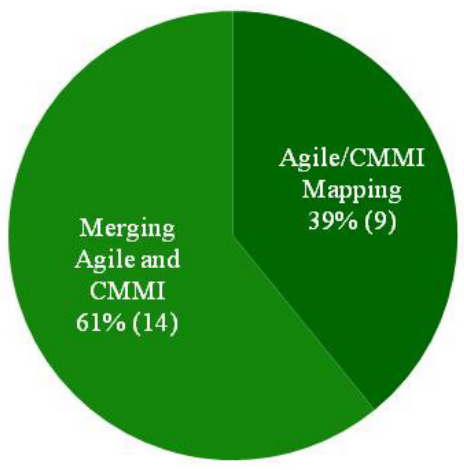

Figure 8. Split in primary themes in Agile/CMMI articles

Sub theme 1-1; Merging of Agile and CMMI. The sub theme "Merging of Agile and CMMI", representing 39\% (9 articles) in theme 1, is primarily concerned with how agile methods can coexist with CMMI in practice without concern for the maturity level. The emerging consensus in this sub theme is the complementary nature of the two disciplines. Firstly some authors (Bass, Allison, \& Banerjee, 2013; Cohan \& Glazer, 2009; Glazer et al., 2008; Paulk, 2001) find the two being complimentary approaches focussing on different aspects of software delivery. Paulk (2001) states the "CMM tells what to do in general terms, but does not say how to do it, while XP is a set of best practices that contains fairly specific how-to information - an implementation model" (Paulk, 2001, p. 6).

This is confirmed when looking at articles where agile is introduced into an organisation and improves the quality of software delivery, without regard of the achieving any CMMI maturity level (Jakobsen \& Johnson, 2008; Jakobsen \& Sutherland, 2009; Koutsoumpos \& Marinelarena, 2013; Leusink, 2012; Morris, 2012; Rönkkö, Peltonen, \& Frühwirth, 2011). Many of this research was con- 
ducted by introducing agile practices into either an already (CMMI) mature environment or where the primary goal was not necessarily maturity but instead successful software delivery. Thus, agile was not implemented in isolation to achieve the maturity rating, which is consistent with the previously mentioned findings.

Sub theme 1-2; Mapping of Agile to CMMI. The sub theme "Mapping of Agile to CMMI" is primarily concerned with the use of agile to either attain or maintain a predetermined CMMI maturity level. The emerging consensus conclusion from the articles is that there is a correlation between agile practices and CMMI process areas, particularly at lower maturity levels (Al-tarawneha, Abdullahb, \& Alic, 2012; Bass et al., 2013; Cintra \& Price, 2006; Fritzsche \& Keil, 2007; Łukasiewicz \& Miler, 2012; Marçal et al., 2008; Omran, 2008; Paulk, 2001). At higher maturity levels there tends to be disagreement with some finding a complete lack of compatibility (Al-tarawneha et al., 2012; Cintra \& Price, 2006; Fritzsche \& Keil, 2007; Lukasiewicz \& Miler, 2012) whilst others find partial compatibility (Bass et al., 2013; Marçal et al., 2008; Omran, 2008; Paulk, 2001). The primary reason proposed for the lack of compatibility at higher levels is the different focus areas, with agile methods focussing on project delivery and CMMI focussing more on the organisational level (Fritzsche \& Keil, 2007; Lukasiewicz \& Miler, 2012). Research findings support this lack of success in agile methods in large organisations (Ambler, 2012; Dingsøyr \& Moe, 2014) when organisational elements such as corporate governance are considered (Laanti, 2014). Though the findings differ, consensus exists to attain higher maturity levels agile practices need to be augmented to satisfy CMMI requirements.

Agile Maturity Model Sub Themes. The major theme of Agile Maturity Models can be further subdivided into research addressing the primary themes of proposing an agile maturity model, how to adopt agile into an environment, agility maturity model assessments, comparisons between existing agile maturity models, and agile process improvement. At 50\%, 8 articles for this major theme concentrate on the sub theme of proposing an agile maturity model (refer to Figure 9). Each of the sub themes will be further discussed in the following sub sections.

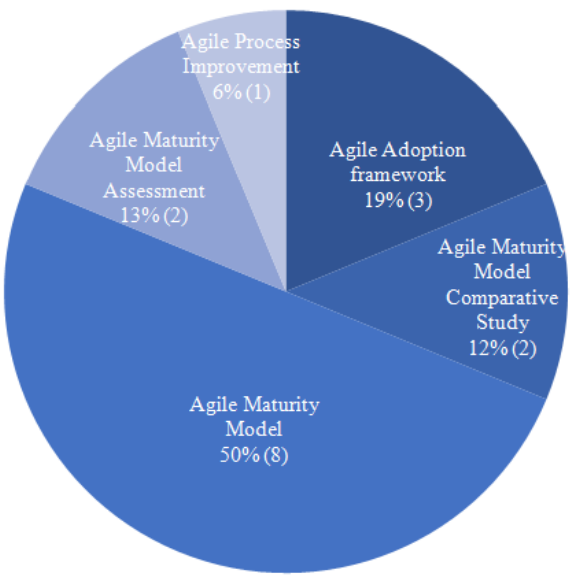

Figure 9. Split in primary themes in Agile Maturity Model articles

Sub theme 2-1; Agile Maturity Model. Agile Maturity models are proposed by a number of researchers, focussing either on a specific methodology (Scrum or XP) such as Nawrocki, Walter, and Wojciechowski (2001) and Yin, da Silva, and Figueiredo (2011) or on general agile practices and principles by Ambler (2010), Benefield (2010), Fontana et al. (2015), and Patel and Ramachandran (2009). The consensus for agile maturity models is, though the maturity level structures and assessments remain, the focus of these models is on ensuring the agility of the implementation environment and adherence to the agile principles.

Sub theme 2-2; Agile Adoption Framework. While similar to agile maturity models, agile adoption frameworks do not necessarily provide maturity levels, focus areas or process areas or assessment 
criteria and are provided by Ambler (2011), Lui and Chan (2005), Packlick (2007), Qumer and Henderson-Sellers (2008), and Sidky, Arthur, and Bohner (2007). These research articles instead focus on how to introduce agile into an environment, regardless of the presence of any current software process improvement frameworks.

Sub theme 2-3; Agile Maturity Model Assessment. Agility assessment studies are focussed on the alignment of the current agile implementation to the agile principles and practices (Benefield, 2010; Fontana et al, 2014; Gren et al., 2015) regardless of whether a maturity model is formally used. Buglione (2011), though, adopts an approach of proposing an assessment model independent of the agile maturity model implemented. Although, because of the team self-organisationing nature of agile teams, agile maturity model assessment can become very team specific (Fontana et al., 2015).

\section{CONCLUSIONS AND FUTURE RESEARCH}

Agile adoption is increasingly being adopted in large corporate environments (VersionOne, 2016). In accord with agile principles, practitioners constantly seek ways to improve the implementation process. The most commonly adopted method in practice is the Consolidated Maturity Model Integrated (CMMI) (Leppänen, 2013), which has shown to be misaligned with agile practices, particularly at higher levels of maturity (Fritzsche \& Keil, 2007). Subsequently research efforts have concentrated on either how to use agile in CMMI environments or how to provide an equivalent maturity model for agile implementations.

This non-empirical study adopted a systematic literature review approach as guided by Kitchenham and Charters (2007), to ascertain the major research themes and trends for maturity models in an agile environment. Online databases were searched for research articles published in online journals or conference proceedings, using the search strings specified in Appendix A - Search Strings. This resulted in an initial list of 531 articles which was filtered to 39 articles for in-depth analysis.

Reviewing the articles and categorising the major themes being investigated shows two primary groupings of interest being "how to make agile methods coexist with CMMI environments" and "how to best define an agile improvement path focussed on agility and aligning to agile principles". The former theme was coded as "Agile/CMMI" (theme 1) and the latter as "Agile Maturity Models" (theme 2), the split in the articles favouring the former by $59 \%$ to $41 \%$ (23 to 16 articles respectively). Articles focussing on the coexistence of agile and CMMI (theme 1) show distinctive peaks in 2008 and 2012, coinciding with the major version updates to the CMMI (Team, 2010). Given the investment CMMI demands (Galin \& Avrahami, 2006; Shrum \& Phillips, 2004), its predominance as a SPI (Leppänen, 2013) and the benefits which can be gained (Galin \& Avrahami, 2006) the focus on the coexistence of agile methods in a CMMI environment is understandable. When viewed in groupings of three year period the agile maturity model themed articles (theme 2) shows an upward trend, with the majority of these articles ( $56 \%=9$ articles) being published in the last 5 years. Interestingly over the same period, theme 1 shows a decreasing trend.

Further analysis of theme 1 shows two primary sub themes being represented, posing the questions "How can agile methods and CMMI be used simultaneously?" and "What is the mapping between a given CMMI level and/or process area and agile practices?". With 61\% (14 articles), the former question represents the majority of the articles and concludes that agile and CMMI are complementary approaches. It is though noteworthy that this is observed in scenarios where agile was either introduced into an organisation with a high level of maturity or where achieving higher maturity was not the primary goal.

Sub-theme 1-1, focussing on how to use agile methods to achieve higher levels of CMMI maturity, concur agile and CMMI are not a natural fit at higher maturity levels (Al-tarawneha et al., 2012; Cintra \& Price, 2006; Fritzsche \& Keil, 2007; Łukasiewicz \& Miler, 2012). These higher maturity levels are more prevalent in larger organisations (Dingsøyr \& Moe, 2014) which continue to show an increase of agile adoption (VersionOne, 2016). It would thus be expected that more research effort 
would be present to address the use of agile in achieving higher levels of CMMI maturity. Though research exists which depicts successful implementation of agile methods in highly mature environments (Bass et al., 2013; Marçal et al., 2008; Omran, 2008; Paulk, 2001), future research could focus on advising how to use agile to mature beyond CMMI maturity level three. Furthermore, whilst the lack of compatibility is attributed to agile not being able to address corporate wide concerns such as governance (Laanti, 2014), little or no research was found on how to address governance in an agile implementation, which presents another possible future research topic.

Sub-theme 2-1, focussing on improving existing software delivery based on agile practices and principles, provide agile maturity models. Given a maturity model provides a framework for improving the performance of a process and the primary outcome of an agile development process is successful software delivery, a future research topic is to investigate how increasing agile maturity relates to project success (Gren et al., 2015).

It can thus be concluded that agile and CMMI can successfully coexist when agile is introduced into already highly mature environments or when the primary goal is focussed solely on the delivery. The common conclusions reviewed in this research indicates if higher levels of CMMI maturity is the goal, agile cannot be used without being supplemented with other non-agile practices.

\section{REFERENCES}

Al-tarawneha, M. Y., Abdullahb, M. S., \& Alic, A. B. (2012). Comparison of extreme programming (XP) method and key process areas of CMMI-DEV1. 2. Computer Science, 1, 1218-1223.

Ambler, S. (2010). The agile maturity model (AMM). Retrieved April 22, 2016, from Dr Dobb's: http://www.drdobbs.com/architecture-and-design/the-agile-maturity-model-amm/224201005

Ambler, S. (2011). Agile adoption strategies: November 2011 survey results. Retrieved April 10, 2016, from Ambysoft: http://www.ambysoft.com/surveys/agileStateOfArt201111.html

Ambler, S. (2012). Agility at scale survey: Results from the Summer 2012 DDJ State of the IT Union Survey. Retrieved March 28, 2016, from Effective Practices for Software Solution Delivery: http://www.ambysoft.com/surveys/stateOfITUnion201209.html

Ambler, S. (2014). Lean and agile software development is more successful than waterfall. Retrieved March 01, 2016, from Scott Ambler and Associates: http://scottambler.com/backup muse/lean-and-agile-softwaredevelopment-is-more-successful-than-waterfall.html

Bass, J. M., Allison, I. K., \& Banerjee, U. (2013). Agile method tailoring in a CMMI level 5 organization. Journal of International Technology and Information Management, 22(4), 77-98.

Benefield, R. (2010). Seven dimensions of agile maturity in the global enterprise: A case study. Proceedings of the 43 rd Hawaii International Conference on System Sciences, (pp. 1-7). Honolulu.

Buglione, L. (2011). Light maturity models (LMM): An agile application. (pp. 57-61). ACM.

Chow, T., \& Cao, D.-B. (2008). A survey study of critical success factors in agile software projects. The Journal of Systems and Software, 81, 961-971.

Cintra, C. C., \& Price, R. T. (2006). Experimenting a requirements engineering process based on rational unified process (RUP) reaching capability maturity model integration (CMMI) maturity level 3 and considering the use of agile methods practices. WER, 153-159.

Cohan, S., \& Glazer, H. (2009). An agile development team's quest for CMMI maturity level 5. Agile Conference 2009 (pp. 201-206). IEEE.

Dingsøyr, T., \& Moe, N. B. (2014). Towards principles of large-scale agile development: A summary of the workshop at XP2014 and a revised research agenda. Conference Paper in Lecture Notes in Business Information Processing.

Dingsøyr, T., Nerur, S., Balijepally, V., \& Brede Moe, N. (2012). A decade of agile methodologies: Towards explaining agile software development. The Journal of Systems and Software, 85, 1213-1221. 
A Systematic Literature Review of Agile and Maturity Model Research

Dybå, T., \& Dingsøyr, T. (2008). Empirical studies of agile software development: A systematic review. Information and Software Technology, 50, 833-859.

Fontana, R. M., Fontana, I. M., da Rosa Garbuio, P. A., Reinehr, S., \& Malucelli, A. (2014). Processes versus people: How should agile software development maturity be defined? The Journal of Systems and Software, 97, 140-155.

Fontana, R. M., Meyer, V. J., Reinehr, S., \& Malucelli, A. (2015). Progressive outcomes: A framework for maturing in agile software. The Journal of Systems and Software, 102, 88-108.

Fowler, M., \& Highsmith, J. (2001). The agile manifesto. Software Development, 9(8), 28-35.

Fritzsche, M., \& Keil, P. (2007). Agile methods and CMMI: Compatibility or conflict? e-Informatics Software Engineering Journal, 1(1), 9-26.

Galin, D., \& Avrahami, M. (2006). Are CMM program investments beneficial? Analyzing past studies. IEEE Software, 23(6), 81-87.

Glazer, H., Dalton, J., Anderson, D., \& Konrad, M. D. (2008). CMMI or agile: Why not embrace both. Technical Report, Carnegie Mellon University, Software Engineering Institute.

Gren, L., Torkar, R., \& Feldt, R. (2015). The prospects of a quantitative measurement of agility: A validation study on an agile maturity model. The Journal of Systems and Software, 107, 38-49.

Heffner, R. (2006). A practical roadmap for transitioning to CMMI v1.2. Northrop Grunman.

Humble, J., \& Russel, R. (2009). The agile maturity model applied to building and releasing software. ThoughtWorks White Paper. Thoughtworks Web Publishing.

Iivari, J., \& Iivari, N. (2011). The relationship between organizational culture and the deployment of agile methods. Information and Software Technology, 53, 509-520.

Jakobsen, C. R., \& Johnson, K. A. (2008). Mature agile with a twist of CMMI. Agile 2008 (pp. 212-217). IEEE.

Jakobsen, C. R., \& Sutherland, J. (2009). Scrum and CMMI - Going from good to great. Agile Conference 2009 (pp. 333-337). IEEE.

Johnson, C. (2002). The benefits of PDCA. Quality Progress, 35(5), 120.

Kitchenham, \& Charters. (2007). Guidelines for performing a systematic literature review in software engineering. Technical Report, Ver. 2.3 EBSE.

Kitson, D., Vickroy, R., Walz, J., \& Wynn, D. (2009). An initial comparative analysis of the CMMI version 1.2 development constellation and the ISO 9000 family. Carnegie Mellon University.

Koutsoumpos, V., \& Marinelarena, I. (2013). Agile methodologies and software process improvement maturity models, current state of practice in small and medium enterprises. Blekinge Institute of Technology, Department of Software Engineering. Unpublished Masters Thesis.

Kuhrmann, M., Diebold, P., \& Münch, J. (2016). Software process improvement: A systematic mapping study on the state of the art. PeerJ Computer Science.

Laanti, M. (2014). Characteristics and principles of scaled agile. Conference Paper in Lecture Notes in Business Information Processing.

Leppänen, M. (2013). A comparative analysis of agile maturity models. In J. C. Rob Pooley (Ed.), Information systems development, reflections, challenges and new directions (pp. 329-343). Springer New York.

Leusink, B. (2012). Agile software development process improvement in large organizations.

Lui, \& Chan. (2005). A road map for implementing extreme programming. In Unifying the Software Process Spectrum; International Software Process Workshop (Vol. 3840, pp. 474-481). Beijing.

Lukasiewicz, K., \& Miler, J. (2012). Improving agility and discipline of software development with the Scrum and CMMI. IET Software, 6(5), 416-422. 
Marçal, A. S., de Freitas, B. C., Soares, F. S., Furtado, M. E., Maciel, T. M., \& Belchior, A. D. (2008). Blending Scrum practices and CMMI project management process areas. Innovations Systems and Software Engineering, 4, 17-29.

McHugh, O., Conboy, K., \& Lang, M. (2012). Agile practices: The impact on trust in software project teams. Software, IEEE, 29(3), 71-76.

Morris, P. D. (2012). The perfect process storm: Integration of CMMI, agile, and lean six sigma. CrossTalk Magazine: The Journal of Defense Software Engineering, 39-45.

Nawrocki, J., Walter, B., \& Wojciechowski, A. (2001). Toward maturity model for extreme programming. Euromicro Conference, 2001. Proceedings. 27th (pp. 233-239). IEEE.

Omran, A. (2008). AGILE CMMI from SMEs perspective. Information and Communication Technologies: From Theory to Applications, 2008. ICTTA 2008. 3rd International Conference on (pp. 1-8). IEEE.

Packlick. (2007). The agility maturity map - A goal oriented approach to agile improvement. Agile Conference 2007, (pp. 266-271).

Patel, C., \& Ramachandran, M. (2009). Agile maturity model (AMM): A software process improvement framework for agile software development practices. International Journal of Software Engineering, 2(1), 328.

Paulk, M. C. (2001). Extreme programming from a CMM perspective. Software IEEE, 18(6), 19-26.

Potter, N., \& Sakry, M. (2009). Implementing Scrum (Agile) and CMMI together. The Process Group Post, 16(2).

Qumer, A., \& Henderson-Sellers, B. (2008). A framework to support the evaluation, adoption and improvement of agile methods in practice. The Journal of Systems and Software, 81, 1899-1919.

Rönkkö, M., Peltonen, J., \& Frühwirth, C. (2011). Examining the effects of agile methods and process maturity on software product development performance. International Conference of Software Business (pp. 85-97). Springer Berlin Heidelberg.

Schweigert, T., Vohwinkel, D., Korsaa, M., \& Nevalai. (2013). Agile maturity model: A synopsis as a first step to synthesis. European Conference on Software Process Improvement (pp. 214-227). Springer Berlin Heidelberg.

Schweigert, T., Vohwinkel, D., Korsaa, M., Nevalainen, R., \& Biro, M. (2014). Agile maturity model: Analysing agile maturity characteristics from the SPICE perspective. Journal of Software: Evolution and Process, 26(5), 513-520.

SEI. (2010). CMMI V1.3 Planned improvements. Carnegie Mellon University, Software Engineering Institute.

Shrum, S., \& Phillips, M. (2004). CMMI overview for executives. Software Engineering Institute.

Sidky, A., Arthur, J., \& Bohner, S. (2007). A disciplined approach to adopting agile practices: The agile adoption framework. Innovations in Systems and Software Engineering, 3(3), 203-216.

Silva, F. S., Soares, F. S., Peres, A. L., de Azevedo, I. M., Vasconcelos, A. P., Kamei, F. K., \& de Lemos Meira, S. R. (2015). Using CMMI together with agile software development: A systematic review. Information and Software Technology, 58, 20-43.

Sutherland, J., Jakobsen, C. R., \& Johnson, K. (2008). Scrum and CMMI Level 5: The magic potion for code warriors. Proceedings of the 41st Hawaii International Conference on System Sciences (pp. 1-9). IEEE.

Team, C. P. (2010). CMMI for development, Version 1.3. Technical Report (CMU/SEI-2010-TR-033), Software Engineering Institute.

VersionOne. (2016). 10th Annual State of Agile Report. Retrieved March 10, 2016, from VersionOne: https://www.versionone.com/?s=state + of + agile

von Wangenheim, C. G., Hauck, J. C., Salviano, C. F., \& von Wangenheim, A. (2010). Systematic literature review of software process capability/maturity models. Proceedings of International Conference on Software Process. Improvement And Capability dEtermination (SPICE). Pisa, Italy.

Yin, A., da Silva, M. M., \& Figueiredo, S. (2011). Scrum maturity model. Proceedings of the ICSEA, (pp. 20-29). 
A Systematic Literature Review of Agile and Maturity Model Research

\section{APPENDiX A - SEARCH STRINGS}

Table A1: List of all possible search strings

\begin{tabular}{|c|c|}
\hline Research String Number & Search String \\
\hline 1 & Agile Maturity Model \\
\hline 2 & Agile Capability Maturity \\
\hline 3 & Agile Process Improvement \\
\hline 4 & Agile Software Maturity \\
\hline 5 & Agile CMM \\
\hline 6 & Agile CMMI \\
\hline 7 & Scrum Maturity Model \\
\hline 8 & Scrum Capability Maturity \\
\hline 9 & Scrum Process Improvement \\
\hline 10 & Scrum Software Maturity \\
\hline 11 & Scrum CMM \\
\hline 12 & Scrum CMMI \\
\hline 13 & XP Maturity Model \\
\hline 14 & XP Capability Maturity \\
\hline 15 & XP Process Improvement \\
\hline 16 & XP Software Maturity \\
\hline 17 & XP CMM \\
\hline 18 & XP CMMI \\
\hline 19 & Extreme Programming Maturity Model \\
\hline 20 & Extreme Programming Capability Maturity \\
\hline 21 & Extreme Programming Process Improvement \\
\hline 22 & Extreme Programming Software Maturity \\
\hline 23 & Extreme Programming CMM \\
\hline 24 & Extreme Programming CMMI \\
\hline 25 & Pair Programming Maturity Model \\
\hline 26 & Pair Programming Capability Maturity \\
\hline 27 & Pair Programming Process Improvement \\
\hline 28 & Pair Programming Software Maturity \\
\hline 29 & Pair Programming CMM \\
\hline 30 & Pair Programming CMMI \\
\hline 31 & Iterative Development Maturity Model \\
\hline 32 & Iterative Development Capability Maturity \\
\hline
\end{tabular}




\begin{tabular}{|c|l|}
\hline Research String Number & Search String \\
\hline 33 & Iterative Development Process Improvement \\
\hline 34 & Iterative Development Software Maturity \\
\hline 35 & Iterative Development CMM \\
\hline 36 & Iterative Development CMMI \\
\hline
\end{tabular}

\section{APPENDIX B - SUMMARY OF CATALOGUING AND CATEGORISATION OF RESEARCH ARTICLES BY PRIMARY RESEARCH THEMES}

Table B1: Cataloguing and categorisation of research themes

\begin{tabular}{|l|l|l|l|l|}
\hline Article \# & Author & Year & Description & $\begin{array}{l}\text { Research } \\
\text { Theme }\end{array}$ \\
\hline A1 & $\begin{array}{l}\text { Qumer and Hen- } \\
\text { derson-Sellers }\end{array}$ & 2008 & $\begin{array}{l}\text { Assess degree of agility required } \\
\text { and appropriate ways to it into } \\
\text { organisation. Develop ASSF (Ag- } \\
\text { ile Software Solution Framework) }\end{array}$ & $\begin{array}{l}\text { Agile Adoption } \\
\text { framework }\end{array}$ \\
\hline A2 & Leppänen & 2013 & $\begin{array}{l}\text { Defines criteria for a maturity } \\
\text { model and provides a useful com- } \\
\text { parison between eight such mod- } \\
\text { els and critique }\end{array}$ & $\begin{array}{l}\text { Agile Maturity } \\
\text { Model Compara- } \\
\text { tive Study }\end{array}$ \\
\hline A3 & $\begin{array}{l}\text { Fritzsche and } \\
\text { Keil }\end{array}$ & 2007 & $\begin{array}{l}\text { Map Agile practices to CMMI } \\
\text { levels using both scrum and XP. }\end{array}$ & $\begin{array}{l}\text { Agile/CMMI } \\
\text { Mapping }\end{array}$ \\
\hline A4 & Leusink & 2012 & $\begin{array}{l}\text { Adopts a specific agile maturity } \\
\text { model, the agile adoption frame- } \\
\text { work and maps to CMMI. Addi- } \\
\text { tionally test the combined model } \\
\text { in practice. }\end{array}$ & $\begin{array}{l}\text { Merging Agile } \\
\text { and CMMI }\end{array}$ \\
\hline A5 & $\begin{array}{l}\text { Patel and Rama- } \\
\text { chandran }\end{array}$ & 2009 & $\begin{array}{l}\text { Provide a five level agile maturity } \\
\text { model based on agile principles } \\
\text { and practices. Evaluates the feasi- } \\
\text { bility of the model at two organi- } \\
\text { sations }\end{array}$ & $\begin{array}{l}\text { Agile Maturity } \\
\text { Model }\end{array}$ \\
\hline Aohwinkel, Kor- \\
and Biro
\end{tabular}




\begin{tabular}{|c|c|c|c|c|}
\hline Article \# & Author & Year & Description & $\begin{array}{l}\text { Research } \\
\text { Theme }\end{array}$ \\
\hline A8 & $\begin{array}{l}\text { Glazer, Dalton, } \\
\text { Anderson and } \\
\text { Konrad }\end{array}$ & 2008 & $\begin{array}{l}\text { Evaluates, critiques and compares } \\
\text { both CMMI \& Agile methods and } \\
\text { makes a case for these to be used } \\
\text { in conjunction as complimentary } \\
\text { approaches }\end{array}$ & $\begin{array}{l}\text { Merging Agile } \\
\text { and CMMI }\end{array}$ \\
\hline A9 & $\begin{array}{l}\text { Rönkkö, Peltonen } \\
\text { and Frühwirth }\end{array}$ & 2011 & $\begin{array}{l}\text { Examines effect of agile in a } \\
\text { CMMI mature environment on } \\
\text { the success of software develop- } \\
\text { ment }\end{array}$ & $\begin{array}{l}\text { Merging Agile } \\
\text { and CMMI }\end{array}$ \\
\hline A10 & Paulk & 2001 & $\begin{array}{l}\text { Critiques practices of XP relative } \\
\text { to CMM }\end{array}$ & $\begin{array}{l}\text { Agile/CMMI } \\
\text { Mapping }\end{array}$ \\
\hline A11 & $\begin{array}{l}\text { Theresa and Ala- } \\
\text { garsamy }\end{array}$ & 2011 & $\begin{array}{l}\text { Map Agile practices to CMMI } \\
\text { levels using XP. }\end{array}$ & $\begin{array}{l}\text { Agile/CMMI } \\
\text { Mapping }\end{array}$ \\
\hline A12 & $\begin{array}{l}\text { Lukasiewicz and } \\
\text { Miler }\end{array}$ & 2012 & $\begin{array}{l}\text { Limited mapping of Scrum to } \\
\text { CMMI to level } 2 \& 3 \text { practices }\end{array}$ & $\begin{array}{l}\text { Agile/CMMI } \\
\text { Mapping }\end{array}$ \\
\hline A13 & Buglione & 2011 & $\begin{array}{l}\text { Proposes an evaluation model for } \\
\text { existing agile maturity model of } \\
\text { your choice. Specifically aimed at } \\
\text { SMEs \& VSEs }\end{array}$ & $\begin{array}{l}\text { Agile Maturity } \\
\text { Model Assess- } \\
\text { ment }\end{array}$ \\
\hline A14 & $\begin{array}{l}\text { Marçal, de Freitas, } \\
\text { Soares, Furtado, } \\
\text { Maciel and Bel- } \\
\text { chior }\end{array}$ & 2008 & $\begin{array}{l}\text { Maps specifically the project man- } \\
\text { agement activities of CMMI to } \\
\text { Scrum practices }\end{array}$ & $\begin{array}{l}\text { Agile/CMMI } \\
\text { Mapping }\end{array}$ \\
\hline A15 & $\begin{array}{l}\text { Jakobsen and } \\
\text { Johnson }\end{array}$ & 2008 & $\begin{array}{l}\text { Apply Scrum in a CMMI level } 5 \\
\text { organisation successfully improv- } \\
\text { ing results }\end{array}$ & $\begin{array}{l}\text { Merging Agile } \\
\text { and CMMI }\end{array}$ \\
\hline A16 & $\begin{array}{l}\text { Fontana, Fontana, } \\
\text { da Rosa Garbuio, } \\
\text { Reinehr and Ma- } \\
\text { lucelli }\end{array}$ & 2014 & $\begin{array}{l}\text { Define shortcomings of trying to } \\
\text { use CMMI thinking in an agile } \\
\text { environment and propose new } \\
\text { definition for agile maturity }\end{array}$ & $\begin{array}{l}\text { Agile Maturity } \\
\text { Model }\end{array}$ \\
\hline A17 & $\begin{array}{l}\text { Fontana, Meyer, } \\
\text { Reinehr and Ma- } \\
\text { lucelli }\end{array}$ & 2015 & $\begin{array}{l}\text { Examine how teams evolve along } \\
\text { agile maturity/adoption paths and } \\
\text { the specific influence of the } \\
\text { teams' dynamics. }\end{array}$ & $\begin{array}{l}\text { Agile Adoption } \\
\text { framework }\end{array}$ \\
\hline A18 & $\begin{array}{l}\text { Jakobsen and } \\
\text { Sutherland }\end{array}$ & 2009 & $\begin{array}{l}\text { Apply Scrum in a CMMI level } 5 \\
\text { organisation successfully improv- } \\
\text { ing results }\end{array}$ & $\begin{array}{l}\text { Merging Agile } \\
\text { and CMMI }\end{array}$ \\
\hline A19 & $\begin{array}{l}\text { Sutherland, Jak- } \\
\text { obsen and John- } \\
\text { son }\end{array}$ & 2008 & $\begin{array}{l}\text { Apply Scrum in a CMMI level } 5 \\
\text { organisation successfully improv- } \\
\text { ing results }\end{array}$ & $\begin{array}{l}\text { Merging Agile } \\
\text { and CMMI }\end{array}$ \\
\hline
\end{tabular}




\begin{tabular}{|c|c|c|c|c|}
\hline Article \# & Author & Year & Description & $\begin{array}{l}\text { Research } \\
\text { Theme }\end{array}$ \\
\hline A20 & $\begin{array}{l}\text { Yin, da Silva and } \\
\text { Figueiredo }\end{array}$ & 2011 & $\begin{array}{l}\text { Propose a five level maturity mod- } \\
\text { el specifically for a scrum envi- } \\
\text { ronment. }\end{array}$ & $\begin{array}{l}\text { Agile Maturity } \\
\text { Model }\end{array}$ \\
\hline A21 & $\begin{array}{l}\text { Nawrocki, Walter } \\
\text { and } \\
\text { Wojciechowski }\end{array}$ & 2001 & $\begin{array}{l}\text { Propose a maturity model specifi- } \\
\text { cally for an XP environment }\end{array}$ & $\begin{array}{l}\text { Agile Maturity } \\
\text { Model }\end{array}$ \\
\hline A22 & Omran & 2008 & $\begin{array}{l}\text { Critique shortcomings of XP rela- } \\
\text { tive to CMMI by mapping CMMI } \\
\text { levels } 2 \text { and } 3 \text { to XP practices }\end{array}$ & $\begin{array}{l}\text { Agile/CMMI } \\
\text { Mapping }\end{array}$ \\
\hline A23 & $\begin{array}{l}\text { Fontana, Reinehr } \\
\text { and Malucelli }\end{array}$ & 2015 & $\begin{array}{l}\text { Provide a method for evaluating } \\
\text { the current state of maturity in an } \\
\text { agile environment. Also conclude } \\
\text { an agile maturity path is not pre- } \\
\text { dictable since each team will adapt } \\
\text { their practices relative to their cir- } \\
\text { cumstances and environment }\end{array}$ & $\begin{array}{l}\text { Agile Maturity } \\
\text { Model Assess- } \\
\text { ment }\end{array}$ \\
\hline A24 & Cohan and Glazer & 2009 & $\begin{array}{l}\text { Provide an experience report on a } \\
\text { planned roadmap to progress } \\
\text { from CMMI } 4 \text { to } 5 \text { using agile } \\
\text { practices }\end{array}$ & $\begin{array}{l}\text { Merging Agile } \\
\text { and CMMI }\end{array}$ \\
\hline A25 & Ambler & 2010 & $\begin{array}{l}\text { Proposes a high level maturity } \\
\text { model for an agile environment. } \\
\text { Only mentions and describes the } \\
\text { different maturity levels and does } \\
\text { not provide any detail on the dif- } \\
\text { ferent focus or process areas or } \\
\text { how to evaluate them. }\end{array}$ & $\begin{array}{l}\text { Agile Maturity } \\
\text { Model }\end{array}$ \\
\hline A26 & $\begin{array}{l}\text { Bass, Allison and } \\
\text { Banerjee }\end{array}$ & 2013 & $\begin{array}{l}\text { Tailor use of agile in an CMMI } \\
\text { Level } 5 \text { organisation and highlight } \\
\text { gaps and supplementary practices } \\
\text { required to fulfil L5 }\end{array}$ & $\begin{array}{l}\text { Agile/CMMI } \\
\text { Mapping }\end{array}$ \\
\hline A27 & $\begin{array}{l}\text { Koutsoumpos } \\
\text { and Marinelarena }\end{array}$ & 2013 & $\begin{array}{l}\text { Investigates which combinations } \\
\text { of SPI models and agile methods } \\
\text { are being used in combination in } \\
\text { industry, specifically focussing on } \\
\text { the use in SMEs }\end{array}$ & $\begin{array}{l}\text { Merging Agile } \\
\text { and CMMI }\end{array}$ \\
\hline A28 & Lee, Kim and Lee & 2008 & $\begin{array}{l}\text { Looks specifically at using XP } \\
\text { processes to achieve CMMI level } 2 \\
\text { processing mapping in small and } \\
\text { medium enterprises }\end{array}$ & $\begin{array}{l}\text { Merging Agile } \\
\text { and CMMI }\end{array}$ \\
\hline
\end{tabular}




\begin{tabular}{|c|c|c|c|c|}
\hline Article \# & Author & Year & Description & $\begin{array}{l}\text { Research } \\
\text { Theme }\end{array}$ \\
\hline A29 & Minh & 2008 & $\begin{array}{l}\text { Focus on CMMI level } 3 \text { in a Vi- } \\
\text { etnam software development } \\
\text { companies, proposes an adaption } \\
\text { of agile methods to con- } \\
\text { form/satisfy CMMI L3. }\end{array}$ & $\begin{array}{l}\text { Merging Agile } \\
\text { and CMMI }\end{array}$ \\
\hline A30 & $\begin{array}{l}\text { Schweigert, Neva- } \\
\text { lainen, Vohwinkel, } \\
\text { Korsaa and Biro }\end{array}$ & 2012 & $\begin{array}{l}\text { Critique of existing agile maturity } \\
\text { models relative to more conven- } \\
\text { tional (CMMI/SPICE) models. } \\
\text { Does not propose agile maturity } \\
\text { model of its own. }\end{array}$ & $\begin{array}{l}\text { Agile Maturity } \\
\text { Model Assess- } \\
\text { ment }\end{array}$ \\
\hline A31 & $\begin{array}{l}\text { Miller and Had- } \\
\text { dad }\end{array}$ & 2012 & $\begin{array}{l}\text { Case study focussing on a L2 } \\
\text { CMMI certification appraisal and } \\
\text { plans for L3 certification; includ- } \\
\text { ing challenges whilst using agile } \\
\text { methods }\end{array}$ & $\begin{array}{l}\text { Merging Agile } \\
\text { and CMMI }\end{array}$ \\
\hline A32 & $\begin{array}{l}\text { Al-tarawneha, } \\
\text { Abdullahb and } \\
\text { Alic }\end{array}$ & 2012 & $\begin{array}{l}\text { Investigate how to map XP prac- } \\
\text { tices to CMMI v1.2 }\end{array}$ & $\begin{array}{l}\text { Agile/CMMI } \\
\text { Mapping }\end{array}$ \\
\hline A33 & Morris & 2012 & $\begin{array}{l}\text { Examines the co-existence of Ag- } \\
\text { ile \& CMMI processes and looks } \\
\text { at a roadmap to integrate these } \\
\text { with other process improvement } \\
\text { frameworks }\end{array}$ & $\begin{array}{l}\text { Merging Agile } \\
\text { and CMMI }\end{array}$ \\
\hline A34 & Benefield & 2010 & $\begin{array}{l}\text { Presents a comprehensive } 5 \text { level } \\
\text { agile maturity model, mapped } \\
\text { against a } 7 \text { level assessment } \\
\text { framework. Quite comprehensive } \\
\text { but limited to XP and specific to } \\
\text { British Telecoms }\end{array}$ & $\begin{array}{l}\text { Agile Maturity } \\
\text { Model }\end{array}$ \\
\hline A35 & Lui and Chan & 2005 & $\begin{array}{l}\text { Presents an adoption framework } \\
\text { for agile teams, specifically in the } \\
\text { Chinese software development } \\
\text { industry }\end{array}$ & $\begin{array}{l}\text { Agile Maturity } \\
\text { Model }\end{array}$ \\
\hline A36 & Packlick & 2007 & $\begin{array}{l}\text { Proposes an agile maturity model } \\
\text { but is limited to specific organisa- } \\
\text { tion }\end{array}$ & $\begin{array}{l}\text { Agile Maturity } \\
\text { Model }\end{array}$ \\
\hline A37 & $\begin{array}{l}\text { Sidky, Arthur and } \\
\text { Bohner }\end{array}$ & 2007 & $\begin{array}{l}\text { Presents a methodology and best } \\
\text { practices for introducing agile } \\
\text { practices into an organisation }\end{array}$ & $\begin{array}{l}\text { Agile Adoption } \\
\text { framework }\end{array}$ \\
\hline A38 & $\begin{array}{l}\text { Salo and Abra- } \\
\text { hamsson }\end{array}$ & 2005 & $\begin{array}{l}\text { Case study focussing on using } \\
\text { agile SPI to integrate into organi- } \\
\text { sational process improvement ini- } \\
\text { tiatives }\end{array}$ & $\begin{array}{l}\text { Agile Process } \\
\text { Improvement }\end{array}$ \\
\hline
\end{tabular}




\begin{tabular}{|l|l|l|l|l|}
\hline Article \# & Author & Year & Description & $\begin{array}{l}\text { Research } \\
\text { Theme }\end{array}$ \\
\hline A39 & Reifer & 2003 & $\begin{array}{l}\text { Argues that agile methods and } \\
\text { CMMI (specifically SW-CMM) is } \\
\text { "philosophically compatible", at } \\
\text { levels 2 and 3. }\end{array}$ & $\begin{array}{l}\text { Merging Agile } \\
\text { and CMMI }\end{array}$ \\
\hline
\end{tabular}

\section{BIOGRAPHIES}

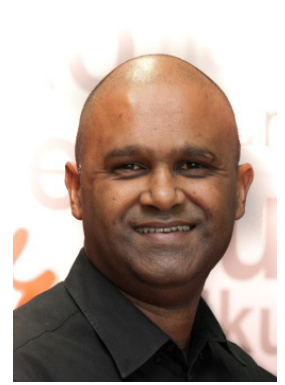

Vaughan Henriques obtained a B Eng (Hons) degree in Electronics Engineering from Canterbury University in 1996 and subsequently a B Com (Hons) degree from the University of Cape Town specializing in Information Systems in 2003 and is presently pursuing a Master's degree in Information Systems at the University of Cape Town. Having 19 years of industry experience spanning various sectors ranging from mining, media, telecoms and financial services, in various roles including software developer, development manager and architecture, his research interests include team motivation, software development methods, IT architecture and design.

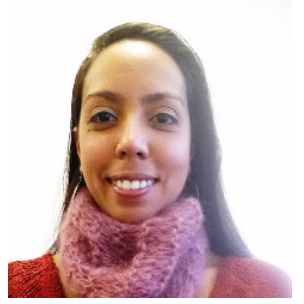

Assoc Professor Maureen Tanner has been teaching systems analysis and design at the Department of Information Systems of the University of Cape Town since 2009. Her research interests lie in Agile software development related issues (for both collocated and distributed teams), UML, software engineering and social aspects of social engineering, global software development, virtual teams, and team collaboration. 